\title{
Influence of synoptic patterns on surface ozone variability over the eastern United States from 1980 to 2012
}

\author{
L. Shen ${ }^{1}$, L. J. Mickley ${ }^{1}$, and A. P. K. Tai ${ }^{2}$ \\ ${ }^{1}$ School of Engineering and Applied Sciences, Harvard University, Cambridge, MA, USA \\ ${ }^{2}$ Earth System Science Programme and Graduate Division of Earth and Atmospheric Sciences, The Chinese University of \\ Hong Kong, Hong Kong, China
}

Correspondence to: L. Shen (1shen@fas.harvard.edu)

Received: 3 April 2015 - Published in Atmos. Chem. Phys. Discuss.: 5 May 2015

Revised: 10 September 2015 - Accepted: 12 September 2015 - Published: 1 October 2015

\begin{abstract}
We investigate the effect of synoptic-scale weather patterns on observed maximum daily 8 -hour average (MDA8) surface ozone over the eastern United States during 1980-2012 in summer (June-August, JJA). Zonally averaged, the relative standard deviation (SD) of daily MDA8 JJA ozone shows a bimodal structure, with peaks at 28-32 and $40-45^{\circ} \mathrm{N}$, and we show that those regions are most influenced by the variability in daily weather. We apply empirical orthogonal functions (EOFs) to understand the causes of this structure. The first three leading EOF patterns explain 53\% of the total variance in detrended surface ozone, displaying (1) a widespread response of ozone in the eastern United States associated with north-south movement of jet wind latitude, (2) a north-south pattern linked to the Bermuda High system when its west boundary is located along the east coast, and (3) an east-west pattern characteristic of a westward extension of the Bermuda High and an enhanced Great Plains low level jet (GPLLJ). The northern peak of ozone relative SD can be explained by polar jet activity, while the southern peak appears related to variability in the Bermuda High and GPLLJ. We define a new metric polar jet frequency as the total number of days the jet traverses the Midwest and northeast each summer. In the Midwest and northeast, we find that the correlation coefficient $r$ between detrended mean JJA MDA8 ozone and the polar jet frequency ranges between -0.76 and -0.93 over 1980-2012 depending on the time period selected, suggesting that polar jet frequency could provide a simple metric to predict ozone variability in future climate regimes. In the southeast, the influence of the Bermuda High on mean JJA MDA8 ozone depends on the location of its west edge. For those summers when the aver-
\end{abstract}

age position of the west edge is located west of $\sim 85.4^{\circ} \mathrm{W}$, a westward shift in the Bermuda High west edge increases ozone in the southeast by $\sim 1 \mathrm{ppbv} \mathrm{deg}^{-1}$ in longitude. For all summers, a northward shift in the Bermuda High west edge increases ozone over the entire eastern United States by $1-2 \mathrm{ppbv} \mathrm{deg}^{-1}$ in latitude. None of the synoptic patterns identified in this study show a significant trend from 1980 to 2012, confirming that the observed ozone decrease over the eastern United States during this time period is mainly caused by emission controls. Our work underscores the impact of synoptic patterns on ozone variability and suggests that a combination of changing local and synoptic meteorology together with trends in background ozone will determine the influence of climate change on US ozone air quality in future decades. The observed relationships of US surface ozone and synoptic circulations in this study can also be used to validate models of atmospheric chemistry.

\section{Introduction}

Ozone is an important air pollutant with potentially large impacts on public health in industrialized and developing regions around the world (Jacob and Winner, 2009; Berman et al., 2012). Both emissions and weather affect surface ozone air quality. High ozone pollution episodes are correlated with high temperatures, low wind speeds, clear skies, and stagnant weather (Camalier et al., 2007; Jacob and Winner, 2009, and references therein), and synoptic-scale weather patterns, with characteristic lengths of $\sim 1000 \mathrm{~km}$, can play a large role in controlling ozone variability (Turner et al., 2013; Zhu and 
Liang, 2013; Logan, 1989). A key issue is to what extent long-term shifts in weather patterns affect surface ozone and whether such shifts may work against ongoing regulatory efforts to control ozone pollution, as has been suggested (e.g., Leibensperger et al., 2008). Here we diagnose the synopticscale meteorological drivers of ozone air pollution in the eastern United States, a region where emissions of ozone precursors have declined dramatically since the 1980s (NEI, http://www.epa.gov/ttn/chief/trends/index.html\#tables). Several observational studies report significant decreases in surface ozone in recent years (e.g., Leibensperger et al., 2008; Bloomer et al., 2009; Cooper et al., 2012). For example, Cooper et al. (2012) found that afternoon surface ozone decreased by $0.45 \mathrm{ppbv} \mathrm{a}^{-1}$ in the eastern United States from 1990 to 2010. In our study, we test whether there are statistically significant trends in synoptic-scale meteorology in the east over the recent decades and, if so, whether such trends have either offset or enhanced the ozone air quality gains from emission reductions. Our work has relevance for ozone air quality in the coming decades, when a climate penalty could undercut regulatory efforts to control pollution (Wu et al., 2008; Wang et al., 2013; Turner et al., 2013).

Previous research linking synoptic-scale circulation to ozone air quality in the northeastern United States has mainly focused on the influence of cyclone frequency (Eder et al., 1993; Vukovich et al., 1995; Hegarty et al., 2007). The cold fronts that accompany cyclones crossing the southern Canada/Great Lakes regions sweep across the northeast, pushing polluted air to the Atlantic and poleward (Leibensperger et al., 2008). In their observational study, Leibensperger et al. (2008) reported a significant decrease in summertime cyclone frequency in southern Canada over 1980-2006, which may have worked against efforts to improve ozone air quality in the northeast. This study appeared to confirm earlier reports of a recent decline in midlatitude cyclone frequency (e.g., McCabe et al., 2001). Climate models have suggested that cyclone frequency could continue to decrease under a future climate change regime (Mickley et al., 2004; Wu et al., 2008; Turner et al., 2013) though large uncertainties exist in these projections (Lang and Waugh, 2011).

More recent work has linked ozone air quality in the eastern United States to the position of the polar jet. Barnes and Fiore (2013) found a strong dependence of surface ozone standard deviation (SD) on the mean June-July-August (JJA) latitude of the polar jet over eastern North America. Changes in the latitude of the polar jet correspond to changes in the storm tracks that cyclones follow as they traverse North America (Hudson, 2012; Archer and Caldeira, 2008), which can have implications for ventilation of ozone pollution in the eastern United States. Using a model, Barnes and Fiore (2013) determined that the variability of US surface ozone followed the robust poleward shift of the polar jet under future climate change scenarios.
Ozone pollution in the eastern United States is also notably influenced by the behavior of the quasi-permanent Bermuda High. The Bermuda High intensifies in summer, and its west boundary can extend deep into the southeast United States ( $\mathrm{Li}$ et al., 2011). In their observational study, Fiore et al. (2003) found that southeast stagnation and increased ozone pollution are linked to westward extension of the Bermuda High, a result consistent with Eder et al. (1993). In their investigation of the impact of the Bermuda High on US air quality, Zhu and Liang (2013) tracked the difference in sea level pressure (SLP) between the Gulf of Mexico and the southern Great Plains. Using this difference as an index, they found that the strength of the Bermuda High is closely related to that of the Great Plains low level jet (GPLLJ), a fast-moving current of air that brings clean maritime air to the Gulf states but carries ozone pollution northward to the northeast. The role of Bermuda High in US ozone pollution has been analyzed in many studies (e.g., Eder et al., 1993; Fiore et al., 2003; Hogrefe et al., 2004; Hegarty et al., 2007), but only Zhu and Liang (2013) have performed a quantitative analysis of this role over a timescale longer than a decade. Using National Centers for Environmental Prediction (NCEP) and ERA-40 Reanalysis data, both Li et al. (2011) and L. Li et al. (2012) diagnosed a strengthening of the summertime Bermuda High and a westward shift of its west edge over 1948-2007. Analysis of an ensemble of models from the Coupled Model Intercomparison Project (CMIP5) reveal that the Bermuda High west edge is expected to shift westward by $\sim 5^{\circ}$ by 2100 due to the stronger thermal contrast between land and ocean (W. Li et al., 2012; Li et al., 2013). The consequences of such a shift on US ozone air quality have not yet been examined.

Few chemistry-climate studies to date have documented either the model capability in capturing the synoptic patterns important to ozone or the sensitivity of modeled ozone to these patterns. For example, using the GFDL-AM3 model, Rasmussen et al. (2012) evaluated only the relationship of ozone with local temperature and not with synoptic patterns. Turner et al. (2013), however, found that this model underestimates the dependence of ozone in the northeast United States on cyclone frequency. To our knowledge, no model study has examined the effect of the westward extent of the Bermuda High on calculated levels of ozone in the southeast United States. As noted by Fiore et al. (2009) and Parrish et al. (2014), chemical transport models (CTMs) and chemistry-climate models (CCMs) have difficulty in simulating observed ozone variability on both seasonal and multiyear timescales, and at least part of this difficulty may be due to model deficiencies in the representation of synoptic patterns and their impact on surface ozone.

In this study, we seek to refine our understanding of the role of synoptic-scale meteorology on the interannual variation of surface ozone pollution in the eastern United States from 1980 to 2012. We will also look for possible trends in the meteorological drivers of ozone and examine the po- 
tential implications for future trends in light of ongoing climate change. We will first apply empirical orthogonal functions (EOFs) to decompose the daily variability of surface JJA maximum daily average 8-hour (MDA8) ozone in the eastern United States over 1980-2012. By examining correlations between the EOF spatial patterns and key meteorological variables such as geopotential height or zonal and meridional wind speed, we can interpret the causes of these patterns. As we will see, ozone variability in the east is controlled by different modes of synoptic-scale circulation, including the polar jet, GPLLJ, and Bermuda High. Our study aims to answer the following questions:

1. What is the percent contribution of synoptic meteorology (vs. local meteorology) to the observed variability in US surface ozone?

2. Have trends in synoptic meteorology either offset or enhanced the ozone air quality gains from emission reductions over the eastern United States in recent decades?

3. What are the implications of changing synoptic meteorology for ozone air quality under future climate regimes?

\section{Ozone and meteorological observations}

Hourly surface ozone concentrations from 1980 to 2012 are obtained from the EPA Air Quality System (EPA-AQS, http: //www.epa.gov/ttn/airs/airsaqs/). We converted the hourly ozone data to MDA8 ozone and then interpolated onto $2.5^{\circ} \times 2.5^{\circ}$ resolution by averaging all observations within each grid cell. For part of this study, MDA8 ozone from the EPA Clean Air Status and Trends Network (CASTNET, http: //epa.gov/castnet/) from 1990 to 2012 is also used. CASTNET sites are mainly located in rural regions, where the anthropogenic influence is less (Cooper et al., 2012).

The meteorological data used in this study consist of wind speed, geopotential height, and SLP from the NCEP Reanalysis 1 with a $2.5^{\circ} \times 2.5^{\circ}$ grid resolution (Kalnay et al., 1996). To remove the effects of intraseasonal variability in meteorology on daily ozone values, we obtain the detrended daily anomaly in each grid cell by subtracting the 30-day moving average in that cell from the daily means as in Tai et al. (2010, 2012). For the seasonal ozone values, the 7-year moving average is subtracted from the seasonal means. The choice of 7 years is arbitrary, but we find that it produces good correlations between surface ozone and meteorological patterns. With ozone observations available only since 1980, it is not appropriate to apply more complicated detrending methods. In detrending surface ozone, our intent is to remove the influence of changing anthropogenic emissions of ozone precursors. Emissions of natural ozone precursors, however, are highly dependent on the interannual variability in meteorology, and their influence on ozone is preserved in the detrended time series. As discussed in Sect. 8 and Table 2, we
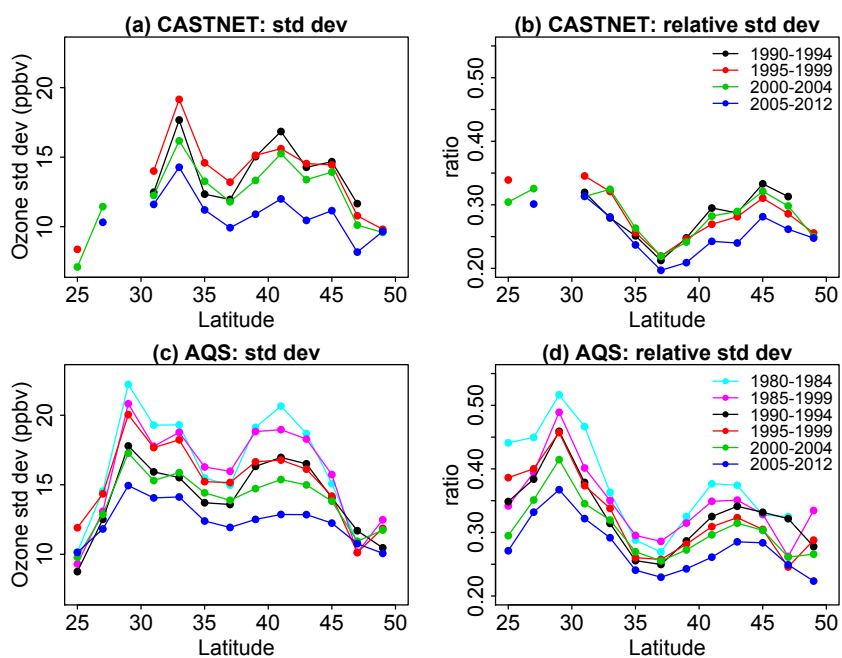

Figure 1. Latitudinal variation of zonal mean ozone standard deviation $(\mathbf{a}, \mathbf{c})$ and relative standard deviation $(\mathbf{b}, \mathbf{d})$ from CASTNET (a, b) and AQS (c, d), averaged between 100 and $65^{\circ} \mathrm{W}$ longitude and binned to $2^{\circ}$ intervals in latitude. All values are for JJA mean MDA8 ozone. The different colors denote different 5-year time intervals except for the most recent interval, which is 8 years in length.

find no significant trends in these meteorological patterns. We focus on JJA ozone, as summer is the season of highest ozone concentrations for most of the United States.

Throughout this study, we use $p<0.05$ as the threshold for statistical significance in our calculations. More specifically, unless otherwise specified, all correlations reported here are statistically significant at the 0.95 confidence level.

\section{Spatial patterns of temporal variability in daily JJA surface ozone in the eastern United States}

As a first step, we investigate patterns of SD in observed summertime daily surface ozone in the eastern United States in summer. Anthropogenic emissions show much less daily variability than regional meteorology, so the ozone SD helps diagnose those regions where synoptic meteorology plays a large role in controlling ozone levels. Both CASTNET and AQS are used in this evaluation. Sites reporting less than $50 \%$ of potential data in any given month are not counted toward our analysis for that summer. We include all sites with at least one summer of observations, resulting in a network of 1670 sites for AQS over 1980-2012 and 72 sites for CASTNET over 1990-2012 in the eastern United States.

Figure 1 reveals a north-south bimodal structure in the zonally averaged variability of daily surface ozone across the eastern United States for a range of time spans. To calculate ozone variability, we proceed as follows. First, we calculate the ozone SD and relative daily SD for each site in each summer. The relative SD is obtained by dividing the ozone SD by the mean JJA MDA8 ozone for that summer. Second, we 
average both kinds of ozone SD over each $2^{\circ}$ latitude bin across the eastern United States for each time span. The relative ozone $\mathrm{SD}$ can isolate much of the effect of different $\mathrm{NO}_{x}$ emission levels by normalizing with mean JJA ozone.

As shown in Fig. 1, both the absolute SD and the relative SD exhibit a bimodal structure over a range of time spans in the AQS and CASTNET data sets. Peaks in absolute SD appear between $29-35$ and $39-43^{\circ} \mathrm{N}$, while peaks in the relative SD appear between $28-32$ and $40-45^{\circ}$ N. From 1980 to 2012, the magnitudes of both kinds of SD diminish due to reductions in the emissions of ozone precursors. The northern peak of SD decreases more rapidly than the southern one (Fig. 1a and c), and this result can be explained by the more dramatic $\mathrm{NO}_{x}$ decreases in the north (Russell et al., 2012). These results are consistent with Bloomer et al. (2009), who found that the ozone-temperature slopes decreased in all ozone percentiles after implementation of the $2002 \mathrm{NO}_{x}$ controls and that these decreases were greatest for ozone in the higher percentiles. Our finding that the relative SD declines over time (Fig. $1 \mathrm{~b}$ and d) is also consistent with Bloomer et al. (2009), as high levels of ozone drop more rapidly than mean ozone does. We also examine the sensitivity of the bimodal structure to the AQS site types (rural, suburban, and urban) and find that the relative SD shows a clear bimodal structure for all time spans and site types (Fig. S1 in the Supplement). The trend in emissions changes only the magnitude of relative SD, with decreases at all latitudes, but it does not erase the bimodal structure. Our results suggest that the ozone relative SD provides a useful metric to gauge the influence of meteorological variability on ozone even as anthropogenic emissions change over time. The persistence of the bimodal structure in relative SD throughout the time period at all AQS site types and at all CASTNET sites increases our confidence that these peaks signify the influence of meteorology and not that of high emissions of anthropogenic precursors.

Because the daily variability in anthropogenic emission is much smaller than that in weather, the bimodal distribution of ozone SD implies that ozone in the northern and southern edges of the eastern United States is especially sensitive to weather variability. The northern peak of relative SD in the CASTNET data has previously been reported by Barnes and Fiore (2013), who suggested that the polar jet wind latitude played a role in formation of this peak. We will revisit the Barnes and Fiore (2013) result in Sect. 5 and propose a mechanism linking the polar jet and surface ozone variability. We will also demonstrate that the southern peak of ozone SD can be explained by the east-west shift of Bermuda High west edge.

To facilitate explanation of the spatial patterns of ozone variability, we divide the eastern United States into four regions, comprising the Midwest, northeast, south-central, and southeast (Fig. 2).

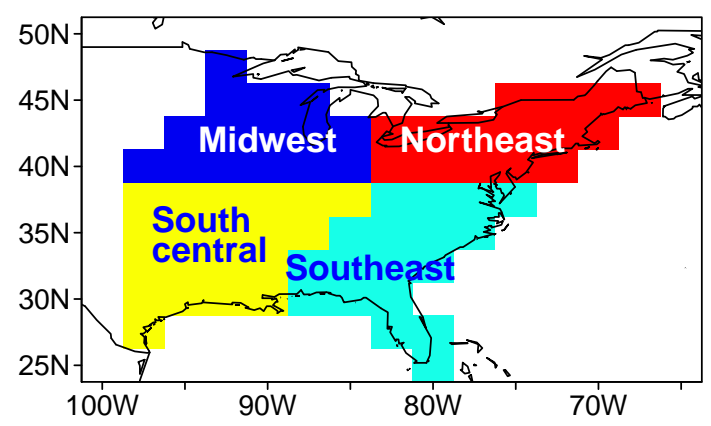

Figure 2. US regions used to study the variability of JJA surface ozone over 1980-2012.

\section{Use of empirical orthogonal functions to diagnose drivers of daily ozone variability}

We next examine the spatial patterns of ozone temporal variability in the eastern United States through the use of EOFs, which are often applied to analyze the variability of atmospheric variables (Eder et al., 1993; Fiore et al., 2003; Weaver and Nigam, 2008; Li et al., 2013). In our case, we use $S$ $(n \times p)$ to represent the detrended daily MDA8 surface ozone concentration in the eastern United States over 1980-2012, where $S$ refers to the ozone concentrations over $n$ daily time steps in $p$ grid boxes. The ozone in each grid box is detrended but not standardized. The temporal covariance between different grid boxes can be written mathematically as $A=S^{\mathrm{T}} S$. The EOF spatial loadings are given by the eigenvectors of $A$, and the corresponding eigenvalues reflect the portion of total variance explained by each EOF. Here we find that the first three EOF patterns can individually explain 24,18 , and $11 \%$ of the variance in surface ozone in the eastern United States, for a total of $53 \%$. Because we are interested in the role of synoptic-scale meteorology on surface ozone, we examine the correlations of each EOF spatial pattern with key meteorological variables such as geopotential height and zonal and meridional wind speed. As we shall see, the use of daily ozone in this EOF analysis provides a clearer picture of the synoptic-scale meteorological variables contributing to ozone variability.

The first EOF pattern (EOF1), which explains $24 \%$ of the total variance in daily MDA8 ozone, displays a broad region of low ozone concentration across the eastern United States, with particularly low values in the upper Midwest and northeast (Fig. 3a). Consistent with previous studies (Eder et al., 1993; Fiore et al., 2003; Leibensperger et al., 2008), we find that EOF1 is associated with a low pressure system crossing the Great Lakes region and accompanied by a cold front carrying clean air from Canada. Figure $3 b$ shows that the negative correlation of the principal components time series for the first mode (PC1) and daily $500 \mathrm{hPa}$ geopotential height is centered just southwest of the Great Lakes region, indicating that the polar jet in this mode extends further south than its 
(a) 1st EOF loading

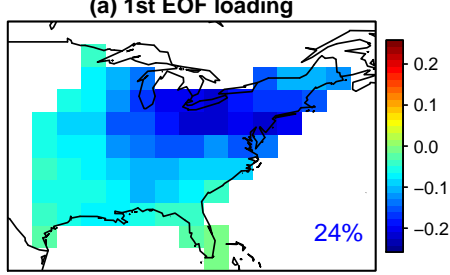

(d) 2nd EOF loading

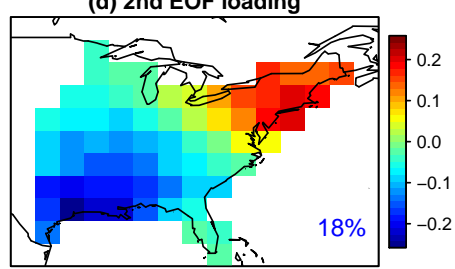

(g) 3rd EOF loading

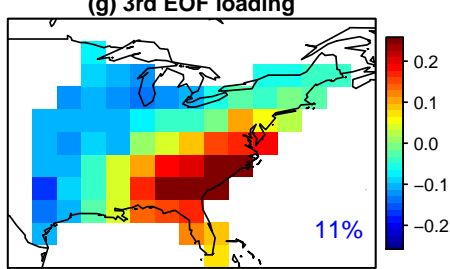

(b) Corr EOF1 with $500 \mathrm{hPa}$ gph

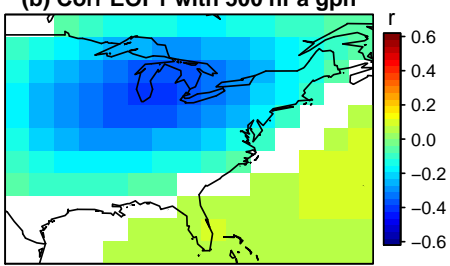

(e) Corr EOF2 with V850

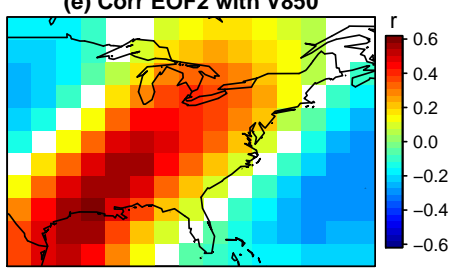

(h) Corr EOF3 with $850 \mathrm{hPa}$ WS

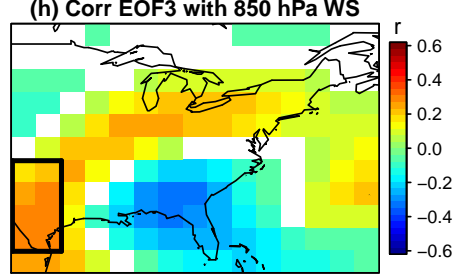

(c) Corr EOF1 with $500 \mathrm{hPa}$ WS

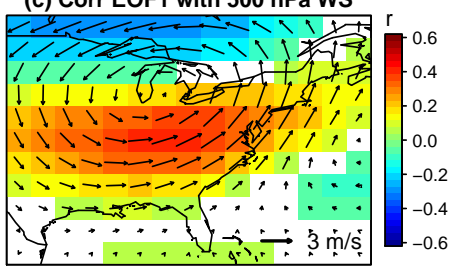

(f) Corr EOF2 with $850 \mathrm{hPa}$ gph

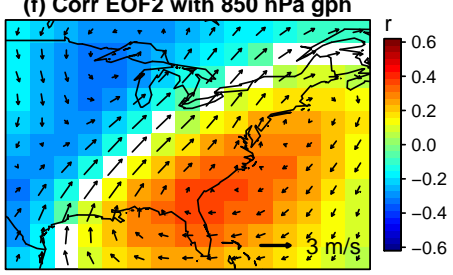

(i) Corr EOF3 with $850 \mathrm{hPa}$ gph

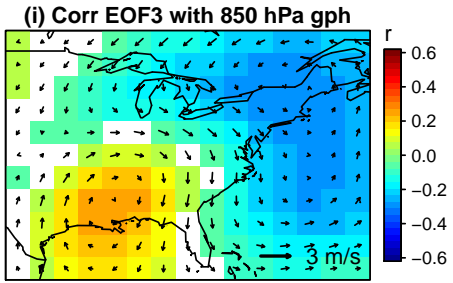

Figure 3. EOF loadings of daily JJA MDA8 ozone from 1980 to 2012 and their correlations with selected meteorological variables. (a) shows the spatial loadings of the first EOF pattern (EOF1) and the correlations $r$ between the principal components time series for the first mode (PC1) and (b) shows daily mean $500 \mathrm{hPa}$ geopotential heights and (c) daily mean $500 \mathrm{hPa}$ wind speeds. Composite $500 \mathrm{hPa}$ wind anomalies associated with positive PC1 are shown as black arrows in (c). (d) is the same as (a) but for the second EOF pattern (EOF2). Also shown are the correlations between PC2 and (e) daily mean $850 \mathrm{hPa}$ meridional wind speed and (f) daily mean $850 \mathrm{hPa}$ geopotential height. The composite $850 \mathrm{hPa}$ wind anomalies with positive PC2 are shown as black arrows in (f). (g) is the same as (a) but for the third EOF pattern (EOF3). Correlations are shown between the PC3 and (h) $850 \mathrm{hPa}$ wind speeds and (i) $850 \mathrm{hPa}$ geopotential heights. (i) also shows the composite $850 \mathrm{hPa}$ wind anomalies associated with positive PC3 (black arrows). White areas indicate either missing data or grid boxes where the correlation is not significant at the 0.05 level.

climatological mean position and forms a trough. As a consequence, cold, clean air is transported to the eastern United States in this mode, and polluted air is pushed off the continent. This type of jet activity, closely associated with cold front passage, plays an important role in pollutant ventilation in the Midwest and northeast (Leibensperger et al., 2008; Jacob and Winner, 2009). The resulting drop in temperature lengthens the lifetime of peroxyacetyl nitrate and reduces the biogenic emission of isoprene, which together also decrease ozone production. Figure $3 \mathrm{c}$ shows the correlation between $\mathrm{PC} 1$ and daily mean $500 \mathrm{hPa}$ wind speeds, as well as the composite $500 \mathrm{hPa}$ wind anomaly when EOF1 is expressed most strongly (i.e., when the PC1 scores are positive and ozone levels are low). The cyclonic anomalous winds, centered over Lake Michigan, sweep over nearly all the eastern United States. The magnitude of this wind pattern oscillates over time, in synchrony with the development and dissipation of cyclonic activity.

The second EOF pattern (EOF2), which explains $18 \%$ of the total variance in JJA daily MDA8 ozone, exerts a significant northeast-southwest contrast in the eastern United States. Figure $3 \mathrm{~d}$ implies that ozone levels over the Gulf states are anti-correlated with those in the northeast in this mode, with decreased ozone over the Gulf states accompanied by increased ozone over the northeast and vice versa. Figure $3 \mathrm{e}$ reveals a strong positive correlation of $\mathrm{PC} 2$ with the daily meridional wind speed, with the greatest correlation centered in a swath extending northward from the southern Great Plains toward the Great Lakes. Figure $3 \mathrm{f}$ shows the correlation of PC2 and $850 \mathrm{hPa}$ geopotential heights. The correlation changes from negative in the Midwest and Texas to positive in the eastern United States, with the change in sign co-located with the strongest correlations of PC2 and meridional transport. The composite wind anomaly associated with the positive PC2 reveals strong onshore winds from the Gulf of Mexico, bringing clean maritime air into the southern Great Plains. As these winds move northeastward, they likely carry aged polluted air from the Midwest to the northeast. This mechanism, also identified by Fiore et al. (2003), accounts for the northeast-southwest EOF pattern in Fig. 3d. The $850 \mathrm{hPa}$ geopotential height is sometimes used to diagnose the Bermuda High (e.g., Li et al., 2011). The pattern of wind anomalies in Fig. $3 \mathrm{f}$ implies that surface ozone in the deep south is lowest when the western boundary lies at 
$\sim 85^{\circ} \mathrm{W}$ longitude and that either the westward or eastward shifts in this boundary increase ozone in this region. As we shall see in Sect. 6, EOF2 is associated with westward expansion of the Bermuda High.

The third EOF pattern (EOF3) explains $11 \%$ of the total variance in JJA daily MDA8 ozone and is characterized by increased ozone in the eastern coastal region coupled with decreased ozone in the Great Plains (Fig. 3g). PC3 correlates with the daily $850 \mathrm{hPa}$ wind speeds in a swath extending from the southern Great Plains to the Great Lakes (Fig. 3h). The positive correlation in the south likely represents the influence of GPLLJ, which ventilates Texas and the central United States, replacing polluted air with clean air from the Gulf. Here we define the GPLLJ as the meridional wind speed at $850 \mathrm{hPa}$ averaged over the region represented by the black rectangle of Fig. 3h $\left(26.25-36.25^{\circ} \mathrm{N}, 101.25-\right.$ $96.25^{\circ} \mathrm{W}$ ). The daily correlation of JJA MDA8 ozone and GPLLJ is negative in the southern Great Plains but positive in the Great Lakes region, mid-Atlantic states, and southeast as shown in Fig. S2, which suggests that the GPLLJ contributes to the observed EOF3 pattern in the south but not in the north. Figure 3i displays the correlation of the PC3 with daily $850 \mathrm{hPa}$ geopotential height, revealing a strong positive relationship in the Gulf region and a negative relationship in the northeast. Comparison of Fig. 3e and $\mathrm{f}$ for EOF2 with Fig. 3h and i for EOF3 suggests that the Bermuda High has extended further west in the EOF3 case. Figure $3 i$ also gives the composite wind anomaly associated with positive PC3, revealing anti-cyclonic anomalous winds centered over Arkansas, Mississippi, and Louisiana. The anomalous winds are consistent with the enhanced GPLLJ wind speeds to the west of the anticyclone (Fig. 3h). This transport pattern brings clean maritime air into Texas and polluted air from the Midwest to the mid-Atlantic states. It also fosters stagnant conditions in Louisiana/Mississippi, increasing ozone there as well.

The negative correlation of PC 3 and geopotential height in the northeast exists not just at $850 \mathrm{hPa}$ but also at $500 \mathrm{hPa}$ (not shown), indicating that the reduced ozone in this region is linked to a stronger polar jet. The EOF3 weather pattern thus connects the GPLLJ in the southern Central Plains with polar jet activity in the northeast. Our result is consistent with Weaver and Nigam (2008), who found that the GPLLJ wind speed appears to be influenced by large-scale circulation patterns.

As a test of our approach, we repeat the EOF analysis using mean JJA MDA8 ozone fields instead of daily mean fields. The top three EOF patterns for the 1980-2012 time period using seasonal mean ozone are similar to those we derive using daily mean ozone (Fig. S3). However the link between EOF3 and $850 \mathrm{hPa}$ geopotential height in this analysis is much weaker than what we find using daily ozone data (Fig. S3i vs. Fig. 3f), and thus the analysis fails to identify the influence of the Bermuda High on ozone air quality (Fig. S3). As we discuss in Sect. 6, the failure arises because the influence of the Bermuda High on ozone varies nonlinearly with the location of the Bermuda High west edge, and the monthly mean EOF analysis obscures this nonlinear relationship. However, the daily data set with its abundance of observations can more easily reveal this fine structure in the EOF analysis.

In the following sections, we take advantage of information gleaned from the EOF analysis to develop a set of metrics that quantify the relationships between surface ozone and synoptic patterns. Such relationships can be implemented in a simple model and readily applied to archive meteorological output from climate models. Although we have so far focused on daily ozone data, we now turn to seasonal mean ozone data. Patterns of many synoptic circulations are noisy on daily timescales, making it challenging to define the metrics needed for our simple model. Such circulations include cyclone frequency (Leipensperger et al., 2008), jet wind latitude (Barnes and Fiore, 2013), and the Bermuda High west edge ( $\mathrm{Li}$ et al., 2011, 2012). The wind speed of the GPLLJ is easier to characterize on daily timescales, and we discuss the effects of daily GPLLJ wind speeds and surface ozone in the Supplement (Fig. S2).

\section{The polar jet as an indicator of seasonal JJA surface ozone concentration in the eastern United States}

The EOF1 pattern of daily ozone variability reveals the influence of the polar jet on surface ozone variability in the northeast and Midwest in the United States (Fig. 3a-c). Here we test three polar jet indices to explore their utility in predicting surface ozone. Care must be taken in constructing an index, as precursor emissions have varied greatly over the past three decades. For example, ozone levels have declined in response to the $\sim 40 \%$ drop in US power plant $\mathrm{NO}_{x}$ emissions beginning in 2002 (Kim et al., 2006; Bloomer, 2008; Bloomer et al., 2009). Such rapid changes in emissions make it challenging to remove their effects on ozone concentrations. As a check on our detrending method, we therefore report the correlation of detrended JJA MDA8 ozone concentration and the three indices over three time periods: 1980-2012 (the entire period), 1993-2012 (the last 20 years), and 2003-2012 (the last 10 years), all summarized in Table 1.

We define the first polar jet index as the mean JJA wind speed at $500 \mathrm{hPa}$ pressure level averaged over the Midwest and northeast, as defined in Fig. 2. Figure 4 shows the time series of mean JJA MDA8 ozone concentrations spatially averaged over these two regions together with the normalized JJA mean $500 \mathrm{hPa}$ polar jet wind speed, illustrating a significant negative correlation between these two variables. The normalization transforms the data to yield zero mean and unit variance but preserves potential trends in the wind speeds. The correlation coefficient $r$ using detrended data is -0.70 over 1980-2012 and increases for more recent time periods $(r=-0.79$ for $1993-2012$ and $r=-0.82$ for 2003 
Table 1. The correlation coefficients $r$ of regionally detrended ${ }^{1}$ mean JJA MDA8 ozone concentration and different meteorological factors in the Midwest and northeast over different time periods. See text for definitions of these factors. All correlations are statistically significant at the 0.05 level.

\begin{tabular}{lrrr}
\hline Meteorological factors & \multicolumn{3}{c}{ Time frame } \\
\cline { 2 - 4 } & $1980-2012$ & $1993-2012$ & $2003-2012$ \\
\hline Jet frequency & -0.76 & -0.87 & -0.93 \\
500 hPa wind speed & -0.70 & -0.79 & -0.82 \\
Jet latitude & 0.66 & 0.74 & 0.85 \\
& $1980-2010$ & $1993-2010$ & $2003-2010$ \\
Cyclone frequency $^{2}$ & -0.69 & -0.58 & -0.74 \\
\hline
\end{tabular}

${ }^{1}$ Data are detrended by subtracting the 7-year moving average from the original data. 2 The 1980-2010 time series of JJA cyclone frequencies is from Turner et al. (2013), calculated over the Great Lakes $\left(70-90^{\circ} \mathrm{W}, 40-50^{\circ} \mathrm{N}\right)$ using NCEP Reanalysis 1 from the MAP Climatology of Mid-latitude Storminess and a cyclone tracking algorithm. Cyclone frequencies for 2011 and 2012 are not available.

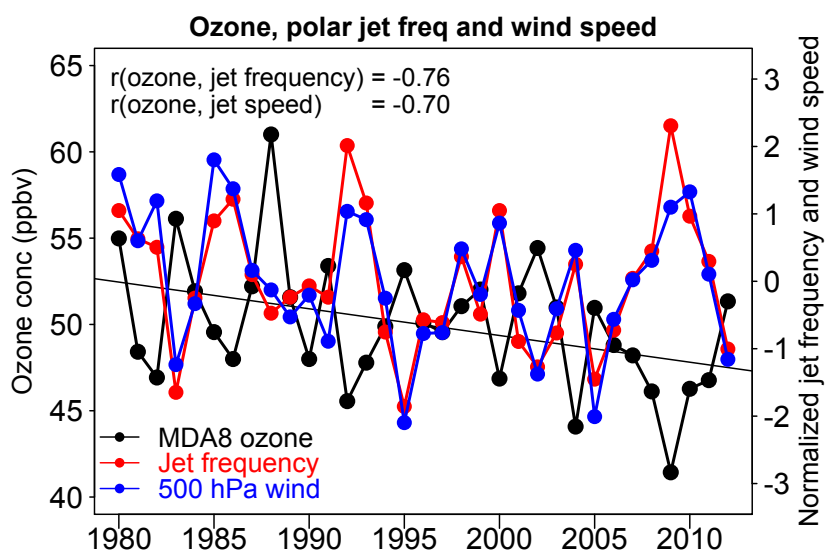

Figure 4. Time series of mean JJA MDA8 surface ozone (ppbv), normalized $500 \mathrm{hPa}$ wind speed, and polar jet frequency, averaged over the combined Midwest and northeast regions (Fig. 2). See text for further details on diagnosis of polar jet. The normalization of wind speed and jet frequency transforms the data to yield zero mean and unit variance. The black solid line denotes the linear trend of ozone over 1980-2012. The correlations of these jet metrics and MDA8 ozone when these data are detrended are inset.

2012). These correlations also increase over time from 0.7 to 0.9 when computed by decade. The increasing correlation $r$ in more recent decades can be partly explained by the greater number of available observations per unit time, which decreases the uncertainty in the calculated relationship between surface ozone and the polar jet indices. In addition, the smaller correlations in the earlier time periods may reflect the challenges in detrending surface ozone, as described above (Kim et al., 2006; Bloomer, 2008; Bloomer et al., 2009). As shown in Fig. 3a-c, greater wind speeds aloft signify a southward shift of the polar jet and faster ventilation, which inhibits ozone accumulation.
The second polar jet index is the polar jet frequency, here defined as the total number of days the jet traverses the Midwest and northeast each summer. To locate the polar jet position on each day, we first divide the region between 25 and $60^{\circ} \mathrm{N}$ into $2.5^{\circ}$ longitude bands and then identify the grid box within each band with the greatest $500 \mathrm{hPa}$ wind speed. For each summer, we sum up the total number of days the polar jet crosses each grid box. Figure 4 also shows the normalized time series of JJA mean polar jet wind frequency in the Midwest and northeast. Its correlation $r$ with detrended JJA ozone concentration is -0.76 over $1980-2012$, and this anticorrelation strengthens in more recent years, with $r=-0.87$ for 1993-2012 and $r=-0.93$ for 2003-2012. Our result implies that a greater frequency of the polar jet wind traversing the Midwest and northeast corresponds to a lower JJA ozone concentration there.

For the third polar jet index, we track the mean JJA jet latitude over time. Following Barnes and Fiore (2013), we define this index as the latitude of the JJA seasonal mean maximum in zonal wind speed at $500 \mathrm{hPa}$ over the Midwest and northeast. We find that a poleward shift of the polar jet latitude increases ozone concentrations in these two regions. The correlation $r$ of the detrended polar jet latitudes with detrended ozone concentrations is 0.66 over 1980-2012 and, like the other indices proposed here, strengthens in more recent decades, with $r=0.74$ for 1993-2012 and 0.85 for 2003-2012.

Summertime cyclone frequency has been previously linked to ozone variability in the northeast (Leibensperger et al., 2008; Turner et al., 2013). We find that the three new polar jet indices perform as well as or even better than cyclone frequency in predicting JJA ozone variability in this region. As a test, we calculate the correlation of detrended JJA MDA8 ozone concentrations averaged over the Midwestnortheast with the detrended cyclone frequency over the Great Lakes from Turner et al. (2013). The calculation yields correlations of -0.69 for $1980-2010,-0.58$ for $1993-2010$, and -0.74 for 2003-2010, as shown in Table 1. Calculation of cyclone frequency typically requires use of a complex storm tracking algorithm and meteorological fields with high temporal frequency (e.g., 6 hourly). An advantage of our approach using polar jet indices to diagnose ozone air quality is that construction of these indices requires only daily mean winds at $500 \mathrm{hPa}$. Thus, this approach makes it significantly easier to project the influence of climate change on ozone, using output routinely archived from climate model simulations. In Sect. 8, we discuss potential trends in polar jet activity and the implications for surface ozone.

\section{Westward extension of the Bermuda High and the impact on seasonal JJA surface ozone}

The EOF2 and EOF3 patterns of JJA surface ozone suggest that the extent of the Bermuda High influences JJA ozone 
Table 2. Linear trends of the synoptic patterns examined in this study over the eastern United States for different time periods.

\begin{tabular}{|c|c|c|c|c|c|c|}
\hline & \multicolumn{3}{|c|}{$\begin{array}{l}\text { Behavior of the polar jet in the } \\
\text { midwest-northeast United States }\end{array}$} & \multicolumn{2}{|c|}{$\begin{array}{l}\text { Bermuda High } \\
\text { west edge }^{2}\end{array}$} & \multirow{2}{*}{$\begin{array}{l}\text { Wind speed of the Great } \\
\text { Plains low level jet }\end{array}$} \\
\hline & $\begin{array}{l}\text { Jet frequency } \\
\left(\text { count } a^{-1}\right)\end{array}$ & $\begin{array}{l}\text { Jet wind speed } \\
\left(\mathrm{m} \mathrm{s}^{-1} \mathrm{a}^{-1}\right)\end{array}$ & $\begin{array}{l}\text { Jet latitude } \\
\quad\left(\operatorname{deg} \mathrm{a}^{-1}\right)\end{array}$ & $\begin{array}{l}\text { BH-Lon }{ }^{3} \\
\left(\operatorname{deg} \mathrm{a}^{-1}\right)\end{array}$ & $\begin{array}{l}\mathrm{BH}^{\mathrm{BLat}}{ }^{4} \\
\left(\operatorname{deg} \mathrm{a}^{-1}\right)\end{array}$ & \\
\hline 1948-2012 & -0.011 & -0.0023 & -0.023 & $-8.2 \times 10^{-3}$ & -0.015 & $3.2 \times 10^{-3}$ \\
\hline 1980-2012 & -0.020 & -0.027 & 0.040 & 0.085 & -0.016 & $-7.3 \times 10^{-5}$ \\
\hline 1980-2006 & $-0.099^{*}$ & $-0.067^{* *}$ & 0.083 & 0.21 & -0.032 & -0.026 \\
\hline
\end{tabular}

variability in the eastern United States. The Bermuda High induces a strong transport of clean air from the Gulf, which can redistribute the pollutants inland (e.g., Fig. 3d and g); the Bermuda High can also create stagnation in regions under high surface pressure (e.g., Fig. 3g). To quantify the influence of the Bermuda High on ozone variability in the east, we build on the work of $\mathrm{Li}$ et al. (2011) and introduce a new definition of the Bermuda High west edge. The west edge, generally defined as a latitude-longitude point, serves as an index of the spatial extent of this quasi-permanent high pressure system, and we will examine the relationships between this index and surface ozone in the east.

Li et al. (2011) defined the Bermuda High west edge in summer as the cross-point of the JJA mean $1560 \mathrm{gpm}$ isoline and the $850 \mathrm{hPa}$ wind ridgeline. The ridgeline refers to the roughly zonal line north of which the easterly trade winds turn westerly, and it can be written mathematically as $u=0$ and $\partial u / \partial y \geq 0$. Use of the seasonal mean geopotential height and ridgeline yields smoother fields and avoids the noisy irregularity inherent in data of finer temporal resolution. Figure S4 shows the interannual variation of JJA $1560 \mathrm{gpm}$ contour lines at $850 \mathrm{hPa}$ and the climatological location of Bermuda High west edge over 1980-2012. Using the west edge as an index of the spatial extent of the Bermuda High, Li et al. (2011) reported a westward shift of Bermuda High west edge from the mid-20th century (1948-1977) to the 1978-2007 period. L. Li et al. (2012) subsequently argued that this westward shift could explain the enhanced variability of summer precipitation in the southeast United States observed in the recent decades.

Here, however, we show that the spatially uniform trend in sea level pressure over much of this region in recent decades reduces the utility of the Li et al. (2011) index of Bermuda High behavior in explaining synoptic-scale circulation. Figure S5a reveals a uniform decrease of sea level pressure of $\sim 4 \mathrm{hPa} \mathrm{a}^{-1}$ over much of the United States and adjacent waters of the Atlantic Ocean from 1980 to 2012, which in turn led to a uniform decrease of geopotential height (not shown) over this region. The spatial uniformity of these trends im- plies little change in the horizontal gradients of geopotential height and thus little change in synoptic-scale circulation. We find that the longitude of Bermuda High west edge (BH-Lon), as defined by $\mathrm{Li}$ et al. (2011), shows a strong negative relationship with the JJA mean SLP averaged over the Bermuda High region $\left(100-40^{\circ} \mathrm{W}, 20-40^{\circ} \mathrm{N}\right)$, with $r$ of -0.65 from 1948 to 2012 (Fig. S5b). Our result suggests that $\sim 40 \%$ of the variability in BH-Lon is caused by spatially uniform changes in sea level pressure or geopotential height, which would have little or no direct effect on circulation patterns.

To better characterize the influence of the Bermuda High west edge on synoptic-scale circulation and thus surface ozone concentration, we proceed as follows. First, we calculate the scaling factors in each year by dividing the 19482012 time series of mean JJA $850 \mathrm{hPa}$ geopotential heights averaged over the Bermuda High domain $\left(40-100^{\circ} \mathrm{W}, 20-\right.$ $40^{\circ} \mathrm{N}$ ) by the climatological mean height at that pressure level for this region $(1564 \mathrm{gpm})$. Second, we divide the $850 \mathrm{hPa}$ geopotential height in each grid box by the scaling factor in that year. As in Li et al. (2011), we then locate the Bermuda High west edge at the cross-point of the adjusted $1560 \mathrm{gpm}$ isoline and the $850 \mathrm{hPa}$ wind ridgeline. This strategy is similar to that used by Li et al. (2013), in which the effect of thermal expansion is removed before calculating trends in the Bermuda High west edge under future climate regimes. We claim our approach allows for more skillful interpretation of trends in circulation patterns, because the horizontal gradient in geopotential height determines the circulation field rather than the isolines themselves. Removing the spatially uniform changes in geopotential heights allows the Bermuda High west edge to better reflect variability in the wind field. As evidence of this skill, our definition of BH-Lon shows better capability in interpreting the interannual variability of GPLLJ than the previous definition. Li et al. (2011) calculated a correlation $r$ between BH-Lon and GPLLJ over 1948-2012 of -0.28 ; our method yields $r=-0.59$. Below we refer to this new definition as the scaled BH-Lon and the definition in Li et al. (2011) as the unscaled BH-Lon. For 


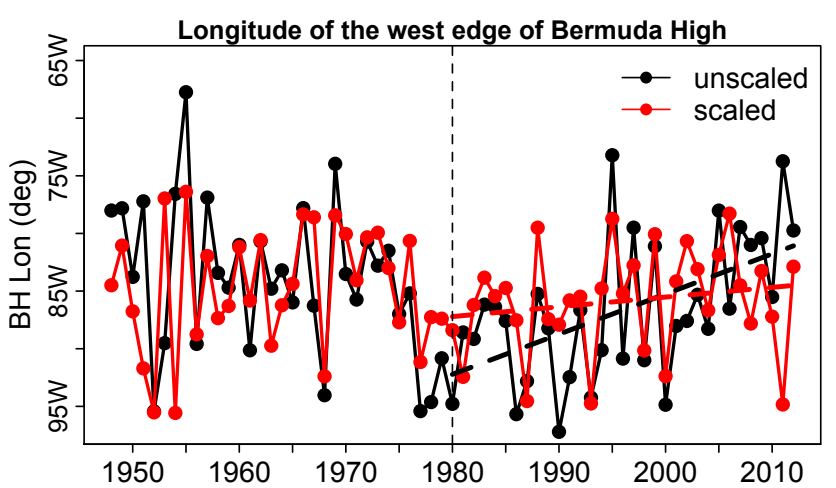

Figure 5. Time series of the longitude of the west edge of the Bermuda High (BH-Lon) in JJA from 1948 to 2012. The black curve represents the unscaled $\mathrm{BH}$-Lon, as defined by the cross-point of the $1560 \mathrm{gpm}$ isoline and the $850 \mathrm{hPa}$ wind ridge line (Li et al., 2011). The red curve represents the scaled BH-Lon, in which the geopotential height field for each summer is scaled by the 1948-2012 average height over the Bermuda High region. The dashed lines show the linear trends of BH-Lon from 1980 to 2012 for the scaled and unscaled cases. See text for further details.

our analysis of the influence of the Bermuda High on surface ozone, we use the scaled BH-Lon.

Using the new definition for BH-Lon, we find that the westward shift in the Bermuda High from the mid-20th century to more recent decades is much diminished compared to that reported by Li et al. (2011). Figure 5 shows the time series of Bermuda High west edges using these two different definitions. From 1948-1977 to 1978-2007, the Bermuda High west edge moved westward by $4.8^{\circ}$ according to $\mathrm{Li}$ et al. (2011) but only $1.2^{\circ}$ in this study. Over the more recent 1980-2012 time period, the BH-Lon trend is $0.35^{\circ} \mathrm{a}^{-1}$ ( $p<0.001$ ) without scaling but shows no significant trend using the definition in this study.

The skill of the Bermuda High west edge in explaining the variability of regional ozone concentration is sensitive to the choice of geopotential isoline in the definition of this index. Using the scaled BH-Lon, we first explore the interannual variability of a range of different isolines at $850 \mathrm{hPa}$, from 1540 to $1575 \mathrm{gpm}$ in $5 \mathrm{gpm}$ increments, eight time series of the Bermuda High west edges in all. We find that the $1560 \mathrm{gpm}$ BH-Lon exhibits the largest variability among all isolines as shown in Fig. S6, with a SD of $\sim 4^{\circ}$ over 1980 2012. As the $1560 \mathrm{gpm}$ BH-Lon migrates west and east, it affects the horizontal gradient of geopotential heights in the lower troposphere, signifying its importance in modulating the regional climate in the southeast. As we shall see, the sign and magnitude of the influence of the Bermuda High west edge on US surface ozone varies from east to west. The 1980-2012 climatological median of $1560 \mathrm{gpm}$ BH-Lon is $85.4^{\circ} \mathrm{W}$. For simplicity, we thus define two regimes for the location of the western edge of the Bermuda High: the West Regime to the west of $85.4^{\circ} \mathrm{W}$ and the East Regime to the east of this longitude. In the West Regime, the $1560 \mathrm{gpm} \mathrm{BH}-$ Lon is associated with enhanced influence of the Bermuda High on the southeast. In the East Regime, the $1560 \mathrm{gpm}$ $\mathrm{BH}-\mathrm{Lon}$ is located to the east of $85.4^{\circ} \mathrm{W}$, corresponding to a reduced Bermuda High influence on the southeast.

For the 17 summers in the West Regime during the 1980 2012 time period, we again test the utility of using different geopotential isolines at $850 \mathrm{hPa}$ in our index for the Bermuda High, this time to determine which choice best predicts surface ozone variability. We find that using the $1555 \mathrm{gpm}$ isoline yields the best correlation of Bermuda High west edges with mean JJA MDA8 ozone averaged across the southeast. For the West Regime summers, we therefore define the Bermuda west edge with this isoline of geopotential height. Figure 6a and $b$ show the response of mean JJA MDA8 ozone across the eastern United States to westward and northward shifts of the adjusted BH-Lon for the 17 West Regime summers. As the $1555 \mathrm{gpm}$ BH-Lon extends westward, surface ozone increases at a rate of $\sim 1 \mathrm{ppbv} \mathrm{deg}^{-1}$ across much of the south, with the greatest positive response in the southeast. The correlations of $1555 \mathrm{gpm}$ BH-Lon and JJA MDA8 ozone is $\sim 0.7$ in the southeast (Fig. S7a). A westward shift of the Bermuda High during West Regime summers strengthens the anticyclonic circulation over the southeast and reduces the moisture flux from the Gulf to the land. These conditions lead, in turn, to more frequent stagnation in the southeast, with enhanced clear skies and warmer temperatures, thereby increasing ozone production and accumulation. Figure $6 \mathrm{~b}$ shows that as the latitude of the Bermuda High (BH-Lat) shifts northward during West Regime summers, mean JJA MDA8 ozone concentrations increase at a rate of $\sim 2 \mathrm{ppbv} \mathrm{deg}^{-1}$ across the southeast, with a positive correlation between ozone and BH-Lon ranging from 0.6 to 0.7 (Fig. S7b). A northward shift in BH-Lat subjects this region to high surface pressures accompanied by warmer temperatures and increased stagnation, again enhancing surface ozone production and accumulation as in the westward shift of BH-Lon.

For the 16 summers in the East Regime, the definition of the Bermuda High west edge using the $1565 \mathrm{gpm}$ isoline shows the best predicative capability and is used to define the Bermuda west edge. In contrast to the West Regime, Fig. $6 \mathrm{c}$ indicates that a westward shift of BH-Lon in this regime leads to reduced mean JJA MDA8 ozone at a rate of $1-2 \mathrm{ppbv} \mathrm{deg}^{-1}$ across the east. The correlation between $1565 \mathrm{gpm}$ BH-Lon and ozone is about -0.7 in the southeast (Fig. S7c). In this regime, a westward shift in BH-Lon signifies that the western flank of the Bermuda High extends further inland, enhancing the transport of clean air from the Gulf along the eastern seaboard. Figure $6 \mathrm{~d}$ displays the response of mean JJA MDA8 ozone to the northward shift of BH-Lat in the East Regime, revealing a strong positive ozone response in the Midwest and northeast, in sharp contrast to the West Regime. There we find a positive correlation of $r=0.40$ ( $p$ value $<0.12$ ) between the JJA mean BH-Lat 

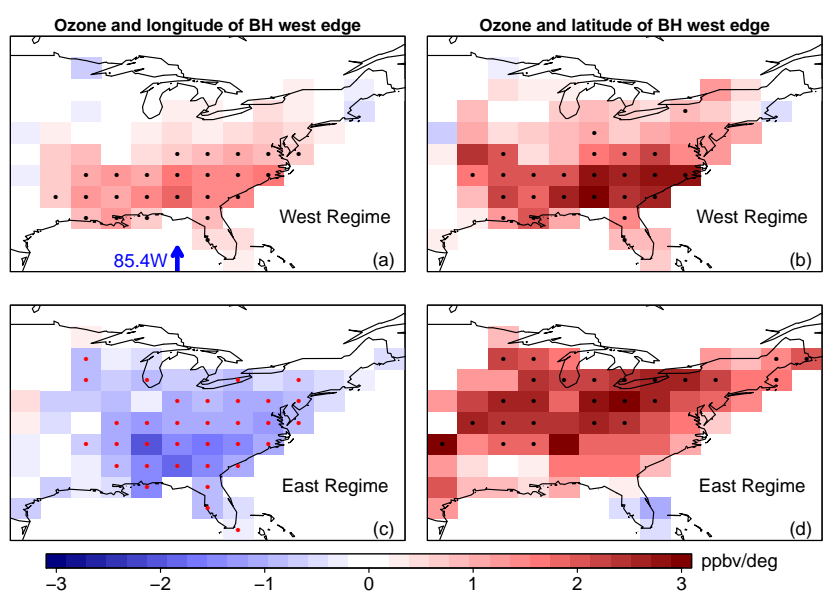

Figure 6. Relationship between the mean JJA MDA8 ozone in the eastern United States and the location of the Bermuda High west edge over the 1980-2012 time period. The plots show the slopes of anomalous ozone vs. longitude (BH-Lon) or latitude (BH-Lat) of the west edge, with the ozone anomalies calculated as the residuals of a 7-year moving average in the AQS data for each grid box. Positive values indicate increasing ozone with westward or northward shifts of the longitude of the Bermuda High west edge. (a and b) show results for those summers when the west edge was located in the West Regime, with the $1560 \mathrm{gpm}$ isoline crossing the $850 \mathrm{hPa}$ wind ridge line west of $85.4^{\circ} \mathrm{W}$. (c and d) show results for the East Regime, when the $1560 \mathrm{gpm}$ isoline crossed the $850 \mathrm{hPa}$ wind ridge line east of $85.4^{\circ} \mathrm{W}$. The location of $85.4^{\circ} \mathrm{W}$ is denoted by the blue arrow in (a). Red and black dots indicate those grid boxes where the slope is significant at the 0.10 level. For more details on the definition of the Bermuda High west edge for each regime, see text.

and geopotential height at $500 \mathrm{hPa}$ for these 16 summers in the East Regime. This result suggests that a northward shift in BH-Lat in the East Regime is sometimes accompanied by a poleward shift in the polar jet latitude, which further enhances surface ozone in the northeastern United States.

\section{Variability in the Great Plains low level jet and implications for seasonal JJA surface ozone}

Here we examine more closely the role of the GPLLJ on ozone in the West and East Regime summers. We find that the response of surface ozone to variability in the GPLLJ depends in part on the location of the Bermuda High west edge. Figure $7 \mathrm{a}$ shows the slopes of the linear relationships of mean JJA MDA8 ozone concentrations to the GPLLJ wind speed for summers in the West Regime over 1980-2012. As before, we define the GPLLJ wind speed as the meridional wind speed at $850 \mathrm{hPa}$ over the southern Great Plains, as indicated in the red rectangle of Fig. 7a. The plot displays significant positive slopes of $\sim 4 \mathrm{ppbv} \mathrm{m}^{-1} \mathrm{~s}$ in the southeast and negative slopes in the southern Great Plains. The enhanced GPLLJ ventilates the southern Great Plains, coincident with the westward shift of the Bermuda High west

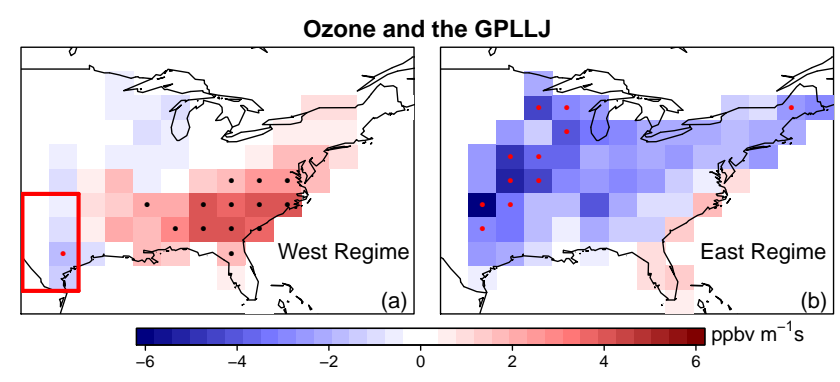

Figure 7. Slopes of anomalous JJA MDA8 ozone vs. GPLLJ in the summers when the Bermuda High is characterized by the (a) West Regime and (b) East Regime during 1980-2012. Ozone concentrations have been detrended as described in text. The West Regime refers to the summers when the west edge of the Bermuda High is located to the west $85.4^{\circ} \mathrm{W}$, while the East Regime is when the west edge is located east of this longitude. See text for further details. Dots indicate grid boxes where the slope is significant at the 0.10 level.

edge and greater stagnation in the southeast under higher surface pressures. The correlation coefficient $r$ of GPLLJ and MDA8 ozone is as high as 0.7 for some grid boxes in the southeast, reflecting the good predictive capability of the speed of the GPLLJ for ozone variability in the West Regime. However, in the East Regime, the influence of the Bermuda High on the eastern United States is reduced. Ventilation by the GPLLJ then becomes the dominant influence on surface ozone across much of the east, and we find negative slopes of mean JJA MDA8 ozone concentration and the GPLLJ wind speed over most of the domain (Fig. 7b). In the shorter time frame of 1993-2008, Zhu and Liang (2013) found that the GPLLJ could bring clean maritime air to the Gulf states while transporting ozone pollution from the Midwest to the northeast and promoting greater stagnation in the southeast. Our study suggests that the influence of the GPLLJ can be decomposed into two parts, according to the location of Bermuda High west edge. In the West Regime, GPLLJ ventilates the south-central states and the westward shift of Bermuda High leads to stagnation in the southeast, consistent with Zhu and Liang (2013). In the East Regime, the influence of Bermuda High is largely reduced and the ventilation by GPLLJ is dominant over the eastern United States.

\section{Percent variability in mean seasonal JJA MDA8 ozone explained by synoptic patterns and trend analysis}

In this section, we quantify the percentage of interannual variability in mean JJA MDA8 ozone that can be explained by the combination of the synoptic patterns identified in this study. We look in particular to see where surface ozone is best explained by these patterns. This step is essential to demonstrate (1) the importance of synoptic-scale meteorology to surface ozone and (2) the need to test the sensitivity 


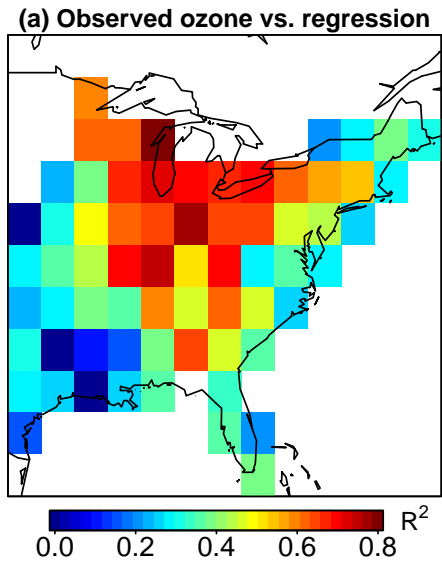

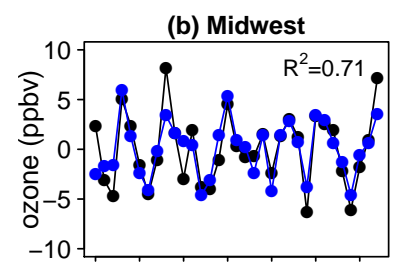

(d) South Central
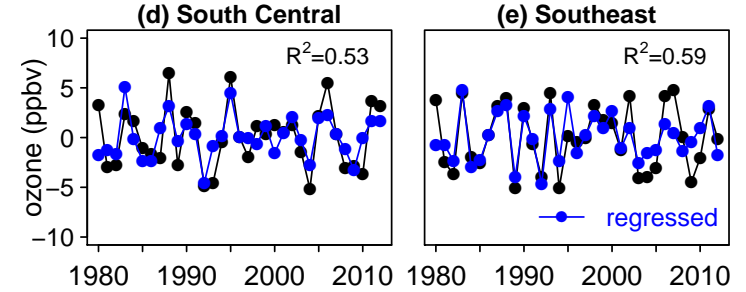

Figure 8. (a) Coefficients of determination $\left(R^{2}\right)$ for the linear regression of mean JJA MDA8 ozone concentration on the meteorological variables describing the polar jet frequency and the Bermuda High west edge from 1980 to 2012. Ozone concentrations have been detrended as described in text. Right-hand panels show the time series of observed (black) and regressed (blue) mean JJA MDA8 ozone concentrations averaged over the Midwest, northeast, south-central region, and southeast. Ozone values have again been detrended in these panels. The correlation coefficient $r$ between the observed ozone and regressed meteorology is shown inset for each region.

of modeled ozone to changing meteorological patterns, especially in chemistry-climate studies. We also examine the observed meteorological data for trends in the key synoptic patterns. Previous studies have reported sometimes contradictory results regarding such trends (e.g., Leibensperger et al., 2008; Turner et al., 2013). Improved knowledge of existing trends in synoptic-scale patterns will allow us to assess to what degree the observed decline in US surface ozone can be attributed to cuts in precursor emissions or to meteorology. If trends in synoptic patterns important to ozone levels have indeed occurred and can be traced to ongoing climate change, such information would benefit policymakers as they plan ahead for future air quality. While future cuts in emissions of ozone precursors could greatly improve air quality, it is not known to what extent policymakers should take the "climate penalty" into account.

We first construct a multiple linear regression model to correlate mean JJA MDA8 ozone and three indices of synoptic-scale circulation: the JJA polar jet frequency and the mean JJA longitude and latitude of the Bermuda High west edge. The model is of the form

$$
\begin{aligned}
& \text { ozone }=\text { Jet-freq+1555 gpm } \\
& \text { BH-Lon } \times \mathrm{I}(\text { west })+1555 \text { gpm BH-Lat } \\
& \times \mathrm{I}(\text { west })+1565 \text { gpm BH-Lon } \times \mathrm{I}(\text { east }) \\
& +1565 \text { gpm BH-Lat } \times \text { I (east })
\end{aligned}
$$

where "ozone" refers to mean JJA MDA8 ozone in ppbv for each grid box, "Jet-freq" is the JJA jet frequency in the Midwest and northeast in count grid $^{-1}$ summer $^{-1}$, "I(West)" and "I(East)" are indicators of West Regime and East Regime based on the Bermuda High west edge, 1555 and 1565 gpm are the isolines used to calculate Bermuda High west edge, and "BH-Lon" and "BH-Lat" are the mean JJA longitudes and latitudes of the Bermuda High west edge as determined for the relevant regime, with both longitudes west and latitudes north assigned positive values. We use a stepwise procedure to delete terms in Eq. (1) based on the Akaike Information Criterion (Venables and Ripley, 2003). Figure 8a compares the model predictions for mean JJA MDA8 ozone with observations over the 1980-2012 time period across the eastern United States. We find the greatest coefficients of determination $\left(R^{2}\right)$ in the Midwest and parts of the northeast and southeast, where the polar jet and the Bermuda High west edge together explain $50-80 \%$ of the interannual variability of mean JJA MDA8 ozone. Time series of observed and predicted mean JJA MDA8 ozone reveal that these two synoptic patterns explain $71 \%$ of the total variance in the Midwest, $59 \%$ in the northeast, $53 \%$ in the south-central, and $59 \%$ in the southeast (Fig. 8b-d).

We find no significant trend of the identified synoptic patterns over the eastern United States for the 1980-2012 period (Table 2). Our results thus support the conclusion of Cooper et al. (2012) that the observed decrease in afternoon surface ozone from 1990 to 2010 was likely caused by tightening emission controls and not by trends in meteorology. Our work is consistent with Bloomer et al. (2010), who found that surface ozone at five CASTNET sites in the eastern United States declined from 1989 to 2007 despite a warming trend $\left(\sim 0.5^{\circ} \mathrm{Cdecade}^{-1}\right)$ in daytime temperatures. Consistent with the Leibensperger et al. (2008) trend analysis of JJA cyclones crossing Canada, we find a significant decrease of the polar jet frequency $\left(-0.099\right.$ count $\left.^{-1}, p<0.1\right)$ and polar jet wind speed $\left(-0.067 \mathrm{~m} \mathrm{~s}^{-1} \mathrm{a}^{-1}, p<0.05\right)$ over the 1980 2006 time period. However, we find no significant trend in these variables over the extended time period of 1980-2012. Turner et al. (2013) reported more frequent midlatitude cyclones crossing the eastern United States since 2006; con- 
sistent with that result, we find increased polar jet frequency since then. Reasons for these short-term variations in polar jet indices are unknown; the variations may be simply caused by natural variability.

\section{Discussion and conclusions}

We investigate the effect of synoptic meteorology on the daily and interannual variability of JJA surface ozone in the United States by using observations from EPA-AQS and the NCEP/NCAR Reanalysis. We identify a bimodal structure in the zonally averaged SD of daily JJA MDA8 ozone over the east, with peaks occurring in the $30-35$ and $39-43^{\circ} \mathrm{N}$ latitude bands, roughly corresponding to the northeast/Midwest and the deep south/Gulf Coast regions. This pattern of variability identifies those regions where surface ozone is the most affected by daily meteorological variability. The pattern is also consistent with the day-to-day variability of detrended daily JJA MDA8 ozone in the eastern United States diagnosed with EOF. The first three leading EOF patterns consist of (1) a widespread response of ozone in the eastern United States associated with north-south movement of jet wind latitude, (2) a north-south pattern associated with the Bermuda High system with its west boundary being located in the coastal regions, and (3) an east-west pattern linked to the westward extension of the Bermuda High and enhanced low level jet transport. EOF3 is also associated with a trough in the polar jet wind over the northeast. Our results reveal that the northern peak of ozone variability in the eastern United States can be explained by the polar jet wind activity and associated cold fronts, while the southern peak can be explained by east-west shifts in the Bermuda High west edge and associated activity of the GPLLJ. None of the three identified synoptic circulations show significant trends in the 1980-2012 time frame. Our result supports the conclusion in Cooper et al. (2012) that the observed decreasing ozone trend is mainly caused by emission control.

We find that a higher frequency of the polar jet wind traversing the Midwest and northeast corresponds to lower surface ozone concentrations. The correlation coefficient $r$ of detrended mean JJA MDA8 ozone and polar jet frequency is -0.76 over $1980-2012,-0.87$ over $1993-2012$, and -0.93 over 1993-2012. The strong interannual correlation of surface MDA8 ozone with polar jet frequency recommends its use as a relatively simple metric to diagnose the effect of climate change on ozone. Previously, the relationship between surface ozone and cyclone frequency has been used to predict ozone variability (Leibensperger et al., 2008; Turner et al., 2012) but calculation of this relationship requires finely time-resolved ( $\leq 6$ hourly) fields of sea level pressure and other variables. In contrast, only the daily mean wind field at $500 \mathrm{hPa}$ is needed to calculate the polar jet frequency. Climate models routinely archive daily mean meteorological fields, but not fields of higher temporal resolution. For this reason, the polar jet frequency could prove to be a useful metric to predict future ozone air quality in multi-model climate projections such as the CMIP5.

We also demonstrate that the influence of the Bermuda High on surface ozone depends on the location of its west edge. In East Regime summers, when the mean longitude of the Bermuda High west edge is east of $85.4^{\circ} \mathrm{W}$, westward movement of the Bermuda High decreases mean JJA MDA8 ozone in the eastern United States by $1-2 \mathrm{ppbv} \mathrm{deg}^{-1}$ in longitude. This influence is due to enhanced flux of clean maritime air onto land as the western flank of the Bermuda High approaches the continent. In West Regime summers, when the mean longitude of the Bermuda High west edge is west of $85.4^{\circ} \mathrm{W}$, westward movement of the Bermuda High west edge increases ozone by $\sim 2 \mathrm{ppbv} \mathrm{deg}^{-1}$ in longitude in the southeast. In this regime, the Bermuda High extends far inland, strengthening the anticyclonic circulation over the southeast and reducing the flux of clean maritime air. As a consequence, the southeast experiences greater air mass stagnation, clear skies, and higher temperatures, all of which favor ozone production and accumulation. Our work goes beyond Zhu and Liang (2013) by showing that the response of surface ozone to variability in the GPLLJ depends on the location of the Bermuda High west edge. As with polar jet frequency, the influence of the Bermuda High on US surface ozone in a future atmosphere could be easily diagnosed from climate model projections.

Afternoon surface ozone decreased at a rate of $0.45 \mathrm{ppbva}^{-1}$ over the eastern United States during the 1990-2010 period (Cooper et al., 2012). Previously, the trends in surface temperature had been explored as a possible driver of this trend (Cooper et al., 2012). We extend this work by searching for trends in the synoptic-scale meteorological patterns identified here as key influences on US surface ozone. We do not find statistically significant trends for either the polar jet frequency or the extent of the Bermuda High over 1980-2012, confirming the hypothesis of Cooper et al. (2012) that the observed decrease in afternoon surface ozone across the east is mainly due to stricter emission controls. Future climate change, however, may bring large changes in the synoptic patterns described here. For example, in their model study, Barnes and Fiore (2013) detected $\mathrm{a} \sim 2^{\circ}$ poleward shift of the JJA polar jet wind in the northeastern United States in the Representative Concentration Pathway 4.5 (RCP4.5) over the 21st century. For a similar time frame in RCP4.5, Li et al. (2013) calculated a $\sim 5^{\circ}$ westward shift of the Bermuda High west edge due to stronger thermal contrast between land and ocean, a consequence of climate change previously suggested by W. Li et al. (2012). Our results suggest that such trends, if realized in the future atmosphere, could seriously degrade ozone air quality over the eastern United States.

Our work identifies the synoptic patterns that strongly influence the variability of US surface ozone, and it provides a set of metrics that may be used to evaluate the skill of CTMs 
and CCMs in capturing this influence. By testing the sensitivity of modeled ozone to the synoptic patterns we identify here, a clearer picture of the causes of model discrepancies should emerge.

This work quantifies the sensitivity of ozone air quality in the eastern United States to the major patterns in synopticscale circulation. However, local meteorological conditions (e.g., Bloomer et al., 2007) and background ozone levels (e.g., Fiore et al., 2002; Wu et al., 2008; Wang et al., 2009) also influence ozone variability in the east, and future climate change could alter these other factors as well. A complete picture of ozone air quality in the coming decades in this region thus requires consideration of all three factors and quantification of their percent contributions to potential change. Our work confirms that the influence of regional meteorology on surface ozone is strong and that future climate change could offset the air quality gains made by planned reductions of ozone precursor emissions (e.g., NRC, 1991; Wu et al., 2008; Wang et al., 2013).

\section{The Supplement related to this article is available online at doi:10.5194/acp-15-10925-2015-supplement.}

Acknowledgements. This work was supported by the National Aeronautics and Space Administration (NASA Air Quality Applied Sciences Team and NASA-MAP grant NNX13AO08G) and by the National Institute of Environmental Health Sciences (NIH grant R21ES022585).

Edited by: S. Brown

\section{References}

Archer, C. L. and Caldeira, K.: Historical trends in the jet streams, Geophys. Res. Lett., 35, L08803, doi:10.1029/2008GL033614, 2008.

Barnes, E. A. and Fiore, A. M.: Surface ozone variability and the jet position: Implications for projecting future air quality, Geophys. Res. Lett., 40, 2839-2844, doi:10.1002/grl.50411, 2013.

Berman, J. D., Fann, N., Hollingsworth, J. W., Pinkerton, K. E., Rom, W. N., Szema, A. M., Breysse, P. N., White, R. H., and Curriero, F. C.: Health benefits from large-scale ozone reduction in the United States, Environ. Health Perspect., 120, 1404-1410, 2012

Bloomer, B. J.: Air pollution response to changing weather and power plant emissions in the eastern United States, PP30, PhD thesis, Univ. of Md., College Park, 174 pp., 2008.

Bloomer, B. J., Stehr, J. W., Piety, C. A., Salawitch, R. J., and Dickerson, R. R.: Observed relationships of ozone air pollution with temperature and emissions, Geophys. Res. Lett., 36, L09803, doi:10.1029/2009GL037308, 2009.
Bloomer, B. J., Vinnikov, K. Y., and Dickerson, R. R.: Changes in seasonal and diurnal cycles of ozone and temperature in the eastern us, Atmos. Environ., 44, 2543-2551, doi:10.1016/j.atmosenv.2010.04.031, 2010.

Camalier, L., Cox, W., and Dolwick, P.: The effects of meteorology on ozone in urban areas and their use in assessing ozone trends, Atmos. Environ., 41, 7127-7137, doi:10.1016/j.atmosenv.2007.04.061, 2007.

Cooper, O. R., Gao, R. S., Tarasick, D., Leblanc, T., and Sweeney, C.: Long-term ozone trends at rural ozone monitoring sites across the United States, 1990-2010, J. Geophys. Res., 117, D22307, doi:10.1029/2012JD018261, 2012.

Eder, B. K., Davis, J. M., and Bloomfield, P.: A characterization of the spatiotemporal variability of non-urban ozone concentrations over the eastern United States, Atmos. Environ., 27, 2645-2668, 1993.

Fiore, A. M., Jacob, D., Bey, I., Yantosca, R., Field, B., Fusco, A., and Wilkinson, J.: Background ozone over the United States in summer: origin, trend, and contribution to pollution episodes, J. Geophys. Res., 107, 4275, doi:10.1029/2001JD000982, 2002.

Fiore, A. M., Jacob, D. J., Mathur, R., and Martin, R. V.: Application of empirical orthogonal functions to evaluate ozone simulations with regional and global models, J. Geophys. Res., 108, 4431, doi:10.1029/2002JD003151, 2003.

Fiore, A. M., Dentener, F. J., Wild, O., Cuvelier, C., Schultz, M. G., Hess, P., Textor, C., Schulz, M., Doherty, R. M., Horowitz, L. W., MacKenzie, I. A., Sanderson, M. G., Shindell, D. T., Stevenson, D. S., Szopa, S., Van Dingenen, R., Zeng, G., Atherton, C., Bergmann, D., Bey, I., Carmichael, G., Collins, W. J., Duncan, B. N., Faluvegi, G., Folberth, G., Gauss, M., Gong, S., Hauglustaine, D., Holloway, T., Isaksen, I. S. A., Jacob, D. J., Jonson, J. E., Kaminski, J. W., Keating, T. J., Lupu, A., Marmer, E., Montanaro, V., Park, R. J., Pitari, G., Pringle, K. J., Pyle, J. A., Schroeder, S., Vivanco, M. G., Wind, P., Wojcik, G., Wu, S., and Zuber, A.: Multimodel estimates of intercontinental sourcereceptor relationships for ozone pollution, J. Geophys. Res., 114, D04301, doi:10.1029/2008JD010816, 2009.

Hegarty, J., Mao, H., and Talbot, R.: Synoptic controls on summertime surface ozone in the northeastern United States, J. Geophys. Res., 112, D14306, doi:10.1029/2006JD008170, 2007.

Hogrefe, C., Biswas, J., Lynn, B., Civerolo, K., Ku, J. Y., Rosenthal, J., Rosenzweig, C., Goldberg, R., and Kinney, P. L.: Simulating regional-scale ozone climatology over the eastern United States: Model evaluation results, Atmos. Environ., 38, 26272638, 2004.

Hudson, R. D.: Measurements of the movement of the jet streams at mid-latitudes, in the Northern and Southern Hemispheres, 1979 to 2010, Atmos. Chem. Phys., 12, 7797-7808, doi:10.5194/acp12-7797-2012, 2012.

Jacob, D. J. and Winner, D. A.: Effect of climate change on air quality, Atmos. Environ., 43, 51-63, 2009.

Kalnay, E., Kanamitsu, M., Kistler, R., Collins, W., Deaven, D., Gandin, L., Iredell, M., Saha, S., White, G., Woollen, J., Zhu, Y., Chelliah, M., Ebisuzaki, W., Higgins, W., Janowiak, J., Mo, K. C., Ropelewski, C., Wang, J., Leetmaa, A., Reynolds, R., Jenne, R., and Joseph, D.: The NCEP/NCAR 40-year reanalysis project, B. Am. Meteorol. Soc., 77, 437-471, 1996.

Kim, S. W., Heckel, A., McKeen, S. A., Frost, G. J., Hsie, E. Y., Trainer, M. K., Richter, A., Burrows, J. P., Peckham, S. E., and 
Grell, G. A.: Satellite-observed US power plant $\mathrm{NO}_{x}$ emission reductions and their impact on air quality, Geophys. Res. Lett., 33, L22812, doi:10.1029/2006g1027749, 2006.

Lang, C. and Waugh, D. W.: Impact of climate change on the frequency of Northern Hemisphere summer cyclones, J. Geophys. Res.-Atmos., 116, D04103, doi:10.1029/2010JD014300, 2011.

Leibensperger, E. M., Mickley, L. J., and Jacob, D. J.: Sensitivity of US air quality to mid-latitude cyclone frequency and implications of 1980-2006 climate change, Atmos. Chem. Phys., 8, 7075-7086, doi:10.5194/acp-8-7075-2008, 2008.

Li, L., Li, W., and Kushnir, Y.: Variation of North Atlantic Subtropical High western ridge and its implication to the Southeastern US summer precipitation, Clim. Dynam., 39, 1401-1412, 2012.

Li, L., Li, W., and Deng, Y.: Summer rainfall variability over the Southeastern United States and its intensification in the 21st century as assessed by CMIP5 models, J. Geophys. Res.-Atmos., 118, 340-354, doi:10.1002/jgrd.50136, 2013.

Li, W., Li, L., Fu, R., Deng, Y., and Wang, H.: Changes to the North Atlan- tic subtropical high and its role in the intensification of summer rainfall variability in the Southeastern United States, J. Climate, 24, 1499-1506, 2011.

Li, W., Li, L., Ting, M., and Liu, Y.: Intensification of Northern Hemisphere subtropical highs in a warming climate, Nat. Geosci., 5, 830-834, 2012.

Logan, J. A.: Ozone in rural areas of the United States, J. Geophys. Res., 94, 8511-8532, 1989.

McCabe, G. J., Clark, M. P., and Serreze, M. C.: Trends in Northern Hemisphere surface cyclone frequency and intensity, J. Climate, 14, 2763-2768, 2001.

Mickley, L. J., Jacob, D. J., Field, B. D., and Rind, D.: Effects of future climate change on regional air pollution episodes in the United States, Geophys. Res. Lett., 31, L24103, doi:10.1029/2004GL021216, 2004.

National Research Council: Rethinking the Ozone Problem in Urban and Regional Air Pollution, Committee on Tropospheric Ozone Formation and Measurement, Natl. Acad. Press, Washington, D.C., 1991.

Parrish, D. D., Lamarque, J.-F., Naik, V., Horowitz, L., Shindell, D. T., Staehelin, J., Derwent, R., Cooper, O. R., Tanimoto, H., Volz-Thomas, A., Gilge, S., Scheel, H.-E., Steinbacher, M., and Fröhlich, M.: Long-term changes in lower tropospheric baseline ozone concentrations: Comparing chemistry-climate models and observations at northern midlatitudes, J. Geophys. Res.-Atmos., 119, 5719-5736, doi:10.1002/2013JD021435, 2014.

Rasmussen, D. J., Fiore, A. M., Naik, V., Horowitz, L. W., McGinnis, S. J., and Schultz, M. G.: Surface ozone-temperature relationships in the eastern us: A monthly climatology for evaluating chemistry-climate models, Atmos. Environ., 47, 142-153, doi:10.1016/j.atmosenv.2011.11.021, 2012.
Russell, A. R., Valin, L. C., and Cohen, R. C.: Trends in OMI $\mathrm{NO}_{2}$ observations over the United States: effects of emission control technology and the economic recession, Atmos. Chem. Phys., 12, 12197-12209, doi:10.5194/acp-12-12197-2012, 2012.

Tai, A. P. K., Mickley, L. J., and Jacob, D. J.: Correlations between fine particulate matter $\left(\mathrm{PM}_{2.5}\right)$ and meteorological variables in the United States: Implications for the sensitivity of $\mathrm{PM}_{2.5}$ to climate change, Atmos. Environ., 44, 3976-3984, 2010.

Tai, A. P. K., Mickley, L. J., Jacob, D. J., Leibensperger, E. M., Zhang, L., Fisher, J. A., and Pye, H. O. T.: Meteorological modes of variability for fine particulate matter $\left(\mathrm{PM}_{2.5}\right)$ air quality in the United States: implications for $\mathrm{PM}_{2.5}$ sensitivity to climate change, Atmos. Chem. Phys., 12, 3131-3145, doi:10.5194/acp12-3131-2012, 2012.

Turner, A. J., Fiore, A. M., Horowitz, L. W., and Bauer, M.: Summertime cyclones over the Great Lakes Storm Track from 1860-2100: variability, trends, and association with ozone pollution, Atmos. Chem. Phys., 13, 565-578, doi:10.5194/acp-13565-2013, 2013.

Venables, W. N. and Ripley, B. D.: Modern Applied Statistics with S. Springer, New York, NY, USA, 2003.

Vukovich, F. M.: Regional-scale boundary layer ozone variations in the eastern United States and their association with meteorological variations, Atmos., Environ., 29, 2259-2273, 1995.

Wang, H., Jacob, D. J., Le Sager, P., Streets, D. G., Park, R. J., Gilliland, A. B., and van Donkelaar, A.: Surface ozone background in the United States: Canadian and Mexican pollution influences, Atmos. Environ., 43, 1310-1319, 2009.

Wang, Y., Shen, L., Wu, S., Mickley, L., He, J., and Hao, J.: Sensitivity of China's ozone air quality to 2000-2050 global changes of climate and emissions, Atmos. Environ., 75, 374-382, 2013.

Weaver, S. J. and Nigam, S.: Variability of the Great Plains lowlevel jet: Large-scale circulation context and hydroclimate impacts, J. Climate, 21, 1532-1551, 2008.

Wu, S., Mickley, L. J., Leibensperger, E. M., Jacob, D. J., Rind, D., and Streets, D. G.: Effects of 2000-2050 global change on ozone air quality in the United States, J. Geophys. Res., 113, D06302, doi:10.1029/2007JD008917, 2008.

Zhu, J. and Liang, X. Z.: Impacts of the Bermuda High on regional climate and ozone over the United States, J. Climate, 26, 10181032, 2013. 